\title{
Influence of Current Forms on Anodic Oxidation of Aluminum in Sulfuric and Oxalic Acids
}

\author{
Sakaé Tajima*, Fujio Satoh*, Nobuyoshi, Baba* \\ and Toshiro Fukushima***
}

Aluminum sheets, 99.99\%, 1/2 $\mathrm{H}$ were anodically oxidized in sulfuric (15 wt.\%) and oxalic (3 wt.\%) acid baths at $30^{\circ}$ and $0^{\circ} \mathrm{C}$ by applying currents of various forms (direct current, single phase-half wave, 3-P non-reversed interrupted, imperfectly rectified, superimposed $(\mathrm{AC}+\mathrm{DC})$, and alternating currents, as shown in Fig. 1, kept at $1 \mathrm{~A} / \mathrm{dm}^{2}$ (mean positive current density) for $30 \mathrm{~min}$.

(1)

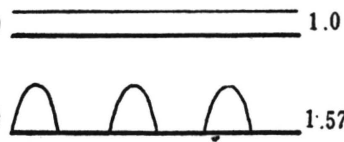

(3)

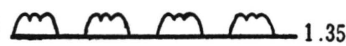

(4)

(5)i

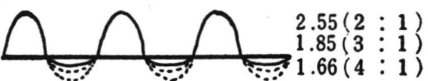

(8)

8) $\mathrm{m} \mathrm{m} \mathrm{m} \mathrm{m} 2.60(2: 1)$

(9)

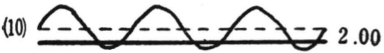

(11)

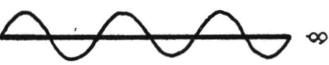

$$
\begin{gathered}
\begin{array}{c}
\text { Direct current } \\
\text { (Battery) }
\end{array} \\
\text { 1-P Half wave }
\end{gathered}
$$

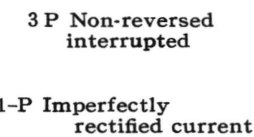

3-P Imperfectly

rectified current

$\mathrm{AC}+\mathrm{DC}$

AC
(1) - -
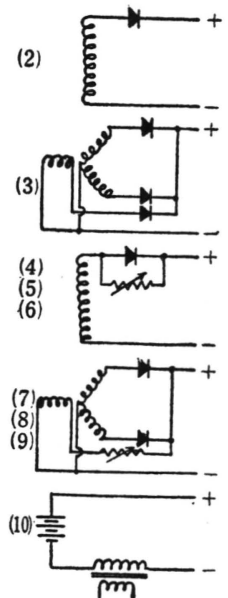

Fig. 1 Various wave forms applied and their circuit diagram.

\begin{tabular}{|c|c|c|c|c|c|c|c|c|}
\hline \multirow{2}{*}{ Current Form } & \multicolumn{2}{|c|}{ Voltage } & \multirow{2}{*}{$\begin{array}{l}\text { Coating } \\
\text { Ratio }\end{array}$} & \multirow{2}{*}{$\begin{array}{c}\text { Thickness } \\
(\mu)\end{array}$} & \multirow{2}{*}{ Density } & \multirow{2}{*}{$\begin{array}{c}\text { Abrasion } \\
\text { Resistance } \\
(\mathrm{sec})\end{array}$} & \multirow{2}{*}{$\begin{array}{c}\text { Hardness } \\
(\mu \text { vickers })\end{array}$} & \multirow{2}{*}{ Appearance } \\
\hline & $\mathrm{DC}(\mathrm{V})$ & $\mathrm{AC}(\mathrm{V})$ & & & & & & \\
\hline Direct Current (Battery) & 13.0 & 13.0 & 1.16 & 8 & 2.46 & 455 & 78 & $\begin{array}{l}\text { Non-colored } \\
\text { transparent }\end{array}$ \\
\hline 1-P Half wave & 13.5 & 14.5 & 1.25 & 8 & 2.66 & 435 & 84 & " $"$ \\
\hline $\begin{array}{l}\text { 3-P Non-renersed } \\
\quad \text { Interrupted }\end{array}$ & 13.0 & 15.5 & 1.22 & 7.5 & 2.76 & 640 & 80 & " " \\
\hline $\begin{array}{l}\text { 1-P Imperfectly } \\
\text { Rectified }(2: 1)\end{array}$ & 4.0 & 10.0 & 1.10 & 7 & 2.32 & 205 & 54 & $\begin{array}{l}\text { Light yellowish- } \\
\text { gold, opaque }\end{array}$ \\
\hline " " $(3: 1)$ & 4.5 & 10.0 & 1.13 & 7 & 2.32 & 225 & 46 & " " \\
\hline " $\quad(4: 1)$ & 4.5 & 10.0 & 1.16 & 7 & 2.42 & 280 & 64 & $"$ \\
\hline $\begin{array}{l}\text { 3-P Imperfectly } \\
\text { Rectified }(2: 1)\end{array}$ & 5.5 & 11.5 & 1.04 & 6.5 & 2.38 & 175 & 48 & $"$ \\
\hline " $\quad(3: 1)$ & 6.5 & 11.5 & 1.08 & 6.5 & 2.46 & 165 & 47 & $"$ \\
\hline$" \quad(4: 1)$ & 8.0 & 11.0 & 1.09 & 7 & 2.25 & 185 & 47 & " \\
\hline Superimposed $(A C+D C)$ & 10.0 & 10.0 & 1.13 & 7 & 2.50 & 370 & 78 & $\begin{array}{l}\text { Non-colored } \\
\text { transparent }\end{array}$ \\
\hline Alternating (AC) & 1.6 & 11.0 & 1.04 & 5.5 & 2.70 & 155 & 43 & $\begin{array}{c}\text { Light yellowish } \\
\text { opaque }\end{array}$ \\
\hline
\end{tabular}

Table 1 Properties of Sulfuric Acid Films $\left(\mathrm{S}_{30}\right)$

$\mathrm{H}_{2} \mathrm{SO}_{4} 15$ wt. $\%, 30^{\circ} \mathrm{C} 1 \mathrm{~A} / \mathrm{dm}^{2}$ (mean positive current), $30 \mathrm{~min}$

* ratio of positive $\left(1 \mathrm{~A} / \mathrm{dm}^{2}\right)$ and negative current

** specified by Japanese Industrial Standards (JIS-H 8601)

* Laboratory of Electrochemistry, Tokyo City University and Chemistry Division, Metropolitan Industrial Research Institute, Tokyo.

** Metropolitan Industrial Research Institute, Tokyo.

The original written in Japanese can be seen in J. Electrochem. Soc. Japan 27,647 (1959). 
The properties of the oxide films thus formed were compared and the results were discussed together with the X-ray diffraction patterns and with the oscillographic analysis of the current and voltage (Lissajous' Figure). Results are summarized as follows :

\section{(1) Bath voltage}

In both sulfuric and oxalic acid baths, the bath

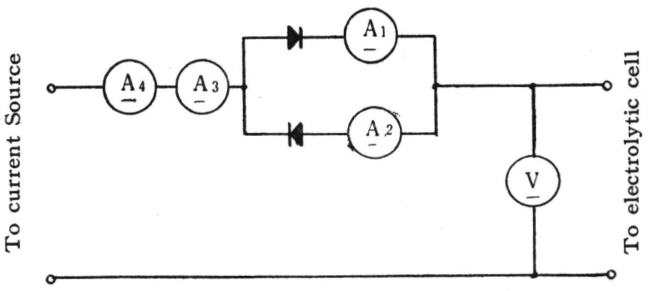

Fig. 2 Current measuring device voltage is very much lower when imperfectly rectified currents containing a negative component are applied as compared with the voltages by currents containing a positive component only. But no remarkable difference in effective values are noticed in both types of current.

\section{(2) Appearance}

By sulfuric acid $\left(30^{\circ} \mathrm{C}\right)$ films, the appearance is not so much different according to the current applied. Usually non-colored transparent films are formed. In spite of this, by the imperfectly rectified currents, the film shows somewhat opaque, light yellowish color.

By oxalic acid films, the colors are yellowish when the current includes a negative component (i.e, in the case of imperfectly rectified and alternating currents) but the color tone is not so much influenced

Table 2 Properties of Oxalic Acid Films (X 30)

$(\mathrm{COOH})_{2} \cdot 2 \mathrm{H}_{2} \mathrm{O} 3 \mathrm{wt} \%, 1 \mathrm{~A} / \mathrm{dm}^{2}$ (mean positive current), $30 \mathrm{~min}$

\begin{tabular}{|c|c|c|c|c|c|c|c|c|}
\hline \multirow{2}{*}{ Current Form } & \multicolumn{2}{|c|}{ Voltage } & \multirow{2}{*}{$\begin{array}{l}\text { Coating } \\
\text { Ratio }\end{array}$} & \multirow{2}{*}{$\begin{array}{c}\text { Thickness } \\
(\mu)\end{array}$} & \multirow{2}{*}{ Density } & \multirow{2}{*}{$\begin{array}{l}\text { Abrasion } \\
\text { Resistance } \\
\quad(\mathrm{sec})\end{array}$} & \multirow{2}{*}{$\left|\begin{array}{c}\text { Hardners } \\
(\mu \text { Vickers })\end{array}\right|$} & \multirow{2}{*}{ Appearance } \\
\hline & $\mathrm{DC}(\mathrm{V})$ & $\mathrm{AC}(\mathrm{V})$ & & & & & & \\
\hline Direct Current (Battery) & 42.0 & 44.0 & 1.27 & 8.5 & 2.6 & 1330 & 70 & $\begin{array}{l}\text { Non-colored, } \\
\text { transparent }\end{array}$ \\
\hline 1-P Half wave & 42.0 & 45.0 & 1.35 & 7.5 & 3.2 & 865 & 112 & $\begin{array}{c}\text { Light yellow, } \\
\text { transparent }\end{array}$ \\
\hline $\begin{array}{l}\text { 3-P Non-reversed } \\
\text { interrupted }\end{array}$ & 42.0 & 45.0 & 1.29 & 7.0 & 2.7 & 980 & 81 & " " \\
\hline $\begin{array}{l}\text { 1-P Imperfectly } \\
\text { rectified }(2: 1)^{*}\end{array}$ & 12.5 & 34.0 & 1.22 & 6.5 & 2.3 & 390 & 40 & Yellowish gold \\
\hline " $\quad(3: 1)$ & 14.0 & 34.0 & 1.20 & 6.5 & 2.5 & 430 & 48 & $"$ \\
\hline " $(4: 1)$ & 14.5 & 36.0 & 1.23 & 7.0 & 2.5 & 580 & 49 & $"$ \\
\hline $\begin{array}{l}\text { 3-P Imperfectly } \\
\text { rectified }(2: 1)\end{array}$ & 18.0 & 33.0 & 1.20 & 5.0 & 2.8 & 225 & 49 & $"$ \\
\hline " " $(3: 1)$ & 23.0 & 35.0 & 1.21 & 5.5 & 2.8 & 580 & 46 & $"$ \\
\hline " $\quad(4: 1)$ & 24.0 & 36.0 & 1.23 & 6.5 & 2.6 & 695 & 46 & $"$ \\
\hline Superimposed $(A C+D C)$ & 24.0 & 25.0 & 1.25 & 7.0 & 3.0 & 670 & 79 & Light yellow \\
\hline $\begin{array}{l}\text { Alternative } \\
\text { current (AC) }\end{array}$ & 4.0 & 40.0 & 1.14 & 4.5 & 2.9 & 205 & 48 & Yellowish gold \\
\hline
\end{tabular}

* Ratio of positive $\left(1 \mathrm{~A} / \mathrm{dm}^{2}\right)$ and negative current

** Specified by Japanese Industrial Standards (JIS-H 8601)

Table 3 Properties of Sulfuric and Oxalic Acid Films at $0^{\circ} \mathrm{C}, 1 \mathrm{~A} / \mathrm{dm}^{2}$ (mean positive current), $30 \mathrm{~min}$.

\begin{tabular}{|c|c|c|c|c|c|c|}
\hline & Form & $\begin{array}{l}\text { Coating } \\
\text { Ratio }\end{array}$ & $\begin{array}{c}\text { Thickness } \\
(\mu)\end{array}$ & Density & $\begin{array}{l}\text { Hardness* } \\
(\mu \text { Vickers })\end{array}$ & Appearance \\
\hline \multirow{3}{*}{$\mathbf{S}_{0}$} & Direct Current (Battery) & 1.65 & 7.0 & 3.8 & $80 \sim 90$ & Glassy gray cracked \\
\hline & 1-P Half wave & 1.72 & 7.5 & $4.4(?)$ & $70 \sim 100$ & $"$ \\
\hline & $\begin{array}{l}\text { 1-P Imperfectly rectified } \\
\qquad(2: 1)^{* *}\end{array}$ & 1.55 & 8.0 & 8.0 & $80 \sim 90$ & Gray, Foams are included \\
\hline \multirow{3}{*}{$\mathbf{X}_{0}$} & Direct current & 1.59 & 8.0 & 3.5 & $80 \sim 90$ & Light yellow, Smooth \\
\hline & 1-P Half wave & 1.63 & 8.0 & 3.5 & $70 \sim 90$ & Yellowish gold, Smooth \\
\hline & $\begin{array}{r}\text { 1-P Imperfectly rectified } \\
(2: 1)\end{array}$ & 1.20 & 8.0 & 1.8 & $70 \sim 90$ & $\begin{array}{l}\text { Deep yellowish gold-brown } \\
\text { Foams are included }\end{array}$ \\
\hline
\end{tabular}

* Not correct values, because the films are thin

** Ratio of positive $\left(1 \mathrm{~A} / \mathrm{dm}^{2}\right)$ and negative currents 
by the quantity a of negative component.

When the temperature is low $\left(0^{\circ} \mathrm{C}\right)$, both films show various deep colors in the case of the imperfectly rectified currents.

(3) Coating ratio

A maximum value was obtained by the single-phase half-wave current and the value becomes smaller in the order of 3-P non-reversed interrupted current, $\mathrm{DC}, \mathrm{AC}+\mathrm{DC}$, imperfectly rectified current and $\mathrm{AC}$ (the smallest). In the imperfectly rectified current, the value is larger by single phase than by 3 phase current and decreases with increase of the negative component.

\section{(4) Apparent Density}

Apparent density of the film is higher by the interrupted currents (single phase-half wave and 3-phase non-reversed interrupted) than by any other of forms current.

(5) Thickness and Microhardness

Here also, the values are highest by the interrupted currents when the mean positive current is the same. But the real hardness can not measured because the films are too thin. The films thicker than

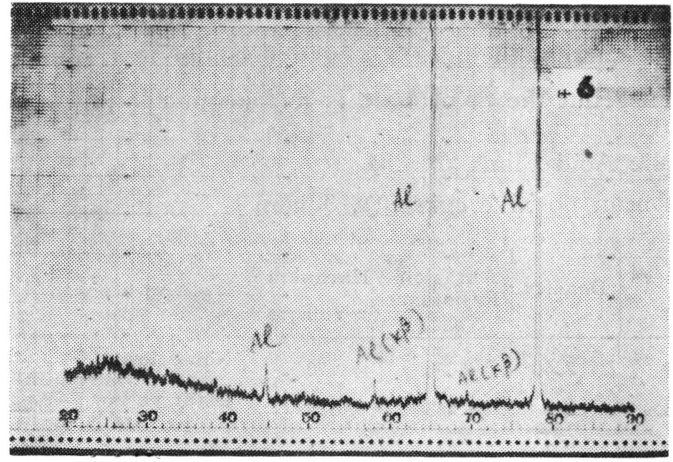

Sulfuric acid $(15 \mathrm{wt} \%), 30^{\circ} \mathrm{C}$, DC $1 \mathrm{~A} / \mathrm{dm}^{2}$

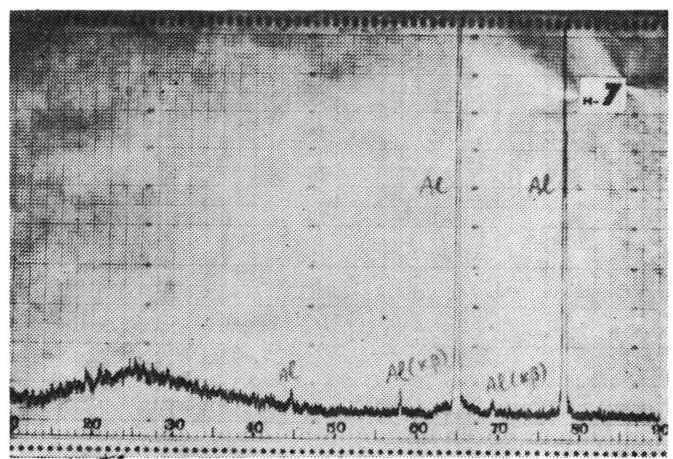

Sulfuric acid $(15 \mathrm{wt} \%) 30^{\circ} \mathrm{C}, 1 \mathrm{P}$ half wave, $1 \mathrm{~A} / \mathrm{dm}^{2}$

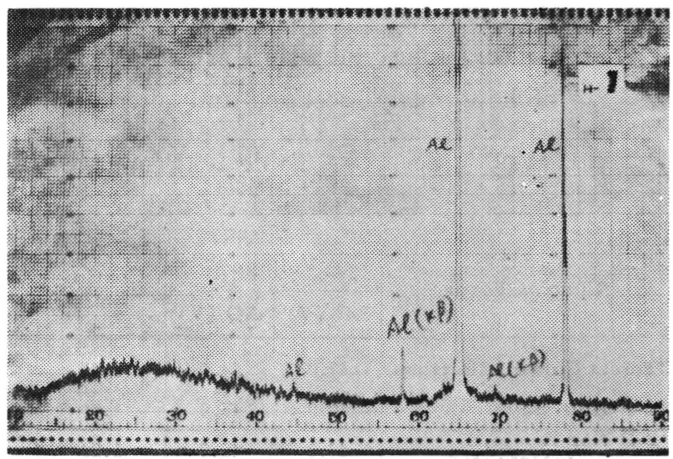

Oxalic acid (3 wt $\%), 30^{\circ} \mathrm{C}$, DC $1 \mathrm{~A} / \mathrm{dm}^{2}$

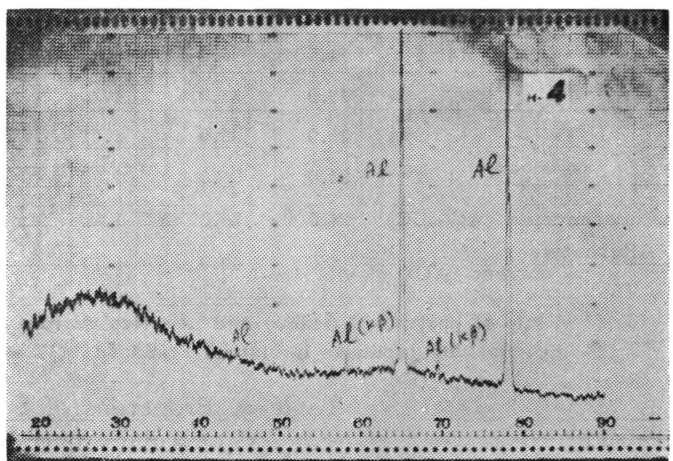

Oxalic acid (3 wt \%) $30^{\circ} \mathrm{C}, 1 \mathrm{P}$ half wave $1 \mathrm{~A} / \mathrm{dm}^{2}$

Condition of Xray diffraction (C. M. Bulb)

\begin{tabular}{l|c||l|c}
\hline \hline Target & $\mathrm{Cu}$ & Scanning Speed & $4^{\circ} / \mathrm{min}$ \\
Filter & $\mathrm{Ni}$ & Divergency & $1^{\circ}$ \\
Voltage & $30 \mathrm{kVP}$ & Chart Speed & $2 \mathrm{~cm} / \mathrm{min}$ \\
Current & $15 \mathrm{~mA}$ & Receiving Slit & $0.2 \mathrm{~mm}$ \\
Count Full Scale & $500 \mathrm{c} / \mathrm{s}$ & Soller Slit & $2.5^{\circ}$ \\
Scale Factor & 8 & Glancing Angle & $5^{\circ}$ \\
Time Constant & $1 \mathrm{sec}$ & Date & 1958.2 .5 \\
Multiplier & 0.8 & & \\
\hline
\end{tabular}

Fig. 3 Results of Xray diffraction 

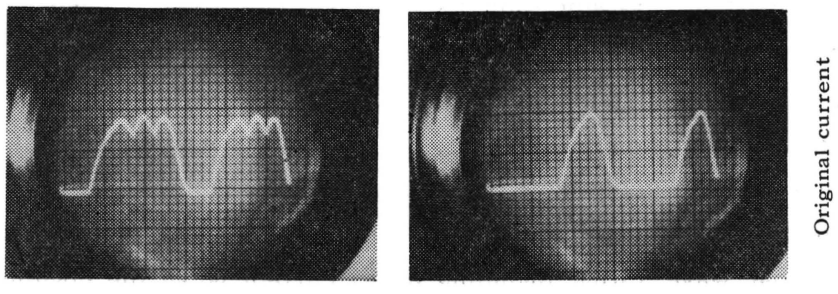

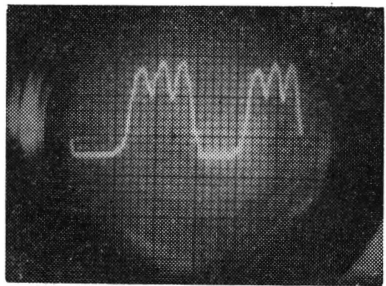

$3 \phi$ Non-reversed interrupted current

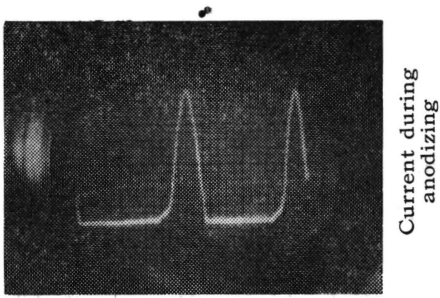

$1 \phi$ Half wave current $\left(2.5 \mathrm{~A} / \mathrm{dm}^{2}\right)$

Fig. 4 Oscillograms of various currents

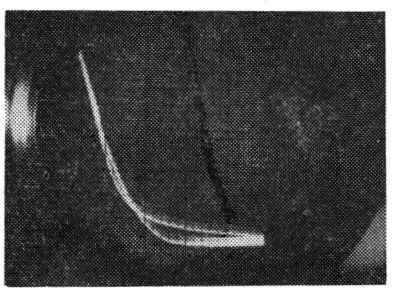

$3 \phi$ Interrupted current $\left(2.5 \mathrm{~A} / \mathrm{dm}^{2}\right)$

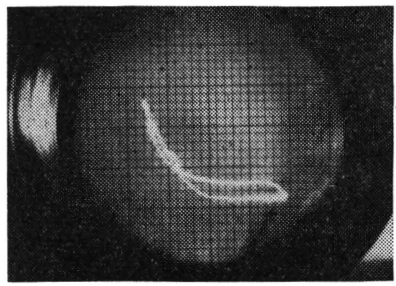

$3 \phi$ Interrupted current $\left(0.5 \mathrm{~A} / \mathrm{dm}^{2}\right)$

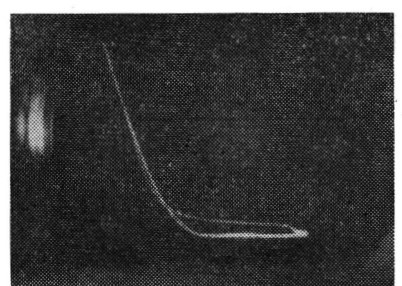

$1 \phi$ Half wave current $\left(2.5 \mathrm{~A} / \mathrm{dm}^{2}\right)$

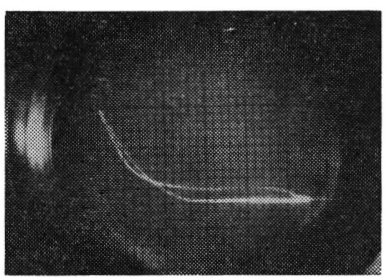

$1 \phi$ Half wave current $\left(0.5 \mathrm{~A} / \mathrm{dm}^{2}\right)$

Fig. 5 Voltage-current Lissajous' figure.

$30 \mu$ formed at $0^{\circ} \mathrm{C}$ showed nearly correct hardness, viz, 300 400 $\mu$ Vickers.

(6) Abrasion resistance after steam-sealing

The coatings by 3-P non-reversed interrupted current and DC show the highest abrasion resistance and those by single phase-half wave and $\mathrm{AC}+\mathrm{DC}$ gave a slightly inferior resistance. The coatings by imperfectly rectified and alternating current gave fairey lower values.

From these observations and from the oscillographic analysis of the voltage and current relations (Fig. 4 and 5), the following considerations were made:-

By the alternate currents, the discharge of hydrogen ion occurs in addition to the usual anodic oxidation, which destroys mechanically the oxide structure in the micropores or promotes the chemical dissolution of the film in the electrolytes, so the properties of films are rather inferior. But the X-ray patterns give similar amorphous oxide structure regardless of the currents applied.

An electrostatic capacitance existing on the electrode surface reduces an anodic (Faradaic) portion of the total current, thus decreasing the current efficiency of the oxide formation. 
By the interrupted current such as single phase-half wave, and 3-P non-reversed interrupted currents, a current larger than the mean value indicated by ammeter passes promptly in a short time, followed by a pause (Fig. 4). Therefore, a good quality film is produced just as in the case of anodizing under a higher current density. Diffusion and cooling of the electrolyte by current interruption also favor preventing the dissolution of the oxide films, thus improving coating ratio etc.

In conclusion, anodizing by interrupted current give, in general, oxide films of the best quality as compared with other possible wave forms including direct current when the positive current density and the total current are the same.

(Received February 7, 1959)

\section{Literature :}

(1) S. Tajima, S. Itō, T. Fukushima, J. Electrochem, Soc. Japan 23, 296, 342, 395 (1955).

(2), (3) S. Tajima, N. Baba, J. Electrochem. Soc. Japan 24, 398 449, (1956).

(4) R.C. Spooner, J. Electrochem. Soc. 102, No. 4, 156 (1955).

(5) Y. Kimura, T. Fukushima, Report of Chemical Division (Metropolitan Industrial Resarch Institute) 14, 47 (1951).

(6) J.D. Edwards F. Keller, Trans. Electrochem. Soc. 79, 135 (1940).

(7) S. Anderson, J.Appl. Phys. 15, 477 (1944).

(8) R.B. Mason, P.E. Fowle, J. Electrochem. Soc. 101, No. 2, 53 (1954).

(9) S. Tajima, T. Fukushima, Y. Kimura, J. Electrochem. Soc. Japan 20, 252 (1952).

(10), (11) S. Tajima, T. Fukushima, Y. Kimura, No. 12, 70 (1954), Metal Fimshing 51, No. 9, 69 (1953). 